\title{
Effects of European and U.S. strains of Fusarium spp. pathogenic to leafy spurge on North American grasses and cultivated species $^{1}$
}

\author{
A. J. CAESAR ${ }^{2}$, G. CAMPOBASSO ${ }^{3}$, and G. TERRAGITTI ${ }^{3}$ \\ ${ }^{2}$ Pest Management and Agricultural Systems Research Unit, Northern Plains Agricultural Research Laboratory, \\ U.S. Department of Agriculture, Agricultural Research Service, Sidney, Montana 59270; and ${ }^{3}$ USDA, ARS European \\ Biological Control Laboratory, Rome Substation, Rome, Italy.
}

\begin{abstract}
:
Host-range tests were conducted in a greenhouse using 9 European and 11 U.S. strains of Fusarium spp. pathogenic to Euphorbia spp. Plants of 12 grass species native to the rangelands of North America were raised from seed, planted in soil infested with each strain, and assessed for dry weight after 24 weeks. Five of 11 U.S. strains of Fusarium spp. significantly reduced the dry weight of at least 1 species of grass native to North America. Only 3 native grass species were affected: Idaho fescue (Festuca idahoensis), big bluestem (Andropogon gerardi), and big bluegrass (Poa ampla). Mean reductions ranged from 56 to $92 \%$. A single European strain caused a $53 \%$ reduction in dry weight of 1 grass species, sand lovegrass (Eragrostis tichodes). Root-dip assays of 3-week-old seedlings in the greenhouse, with assessment over 3 weeks followed by 9 weeks of further observation and recording of dry weights of surviving plants were used to assess pathogenicity to 27 cultivated plant species. Two of the 3 most virulent U.S. strains failed to cause disease on any crop species according to these criteria. Three U.S. strains were positive in root-dip assays, each to a single crop species, causing vascular discoloration of flax (Linum ussitatissimum) and root necrosis of okra (Hibiscus esculentus) and cotton (Gossypium hirsutum). Neither of the 2 most virulent European strains exhibited pathogenicity to any of 12 crop species. Two other European strains exhibited host ranges comprised of 3 and 4 crop species. Two strains of $F$. proliferatum from the U.S. and Europe differing in host range were vegetatively compatible. The greater frequency of disease incidence on Euphorbia in Europe and the narrow host range and apparently greater
\end{abstract}

\footnotetext{
${ }^{1}$ Received March 24, 1998; accepted February 1, 1999.
} 
virulence of European strains indicate that strains well-adapted to leafy spurge might best include Fusarium spp. occurring in Europe.

\section{Keywords:}

Biological control; mycoherbicide; rangeland weeds; Euphorbia esula, Andropogon gerardi, Eragrostis tichodes, Festuca idahoensis, Poa ampla.

Leafy spurge (Euphorbia esula L./virgata (L.) Waldst. \& Kit.) is the most economically damaging perennial weed in the rangelands of the Northern Plains of the United States and the Prairie Provinces of Canada. It is an exotic weed with a native range that extends from western Europe to northeast China. Negative effects of the weed include reduced grazing capacity of rangelands due to toxicity to livestock and displacement or suppression of native range species, both leading to decreased land values. Economic losses are estimated to exceed \$43.9 million (Bangsund and Leistritz, 1991), and there is the threat of increased infestation of croplands in the Northern Plains. Fusarium spp. have been isolated and described from diseased and dying leafy spurge plants found in natural stand-declines that occur rarely or in small patches in large stands of leafy spurge in the United States (Caesar, 1996). Diseased Euphorbia spp. are also found frequently in Europe (Caesar et al., 1998), where the plant is widespread in small stands and is typically infested with one or more insects, including root-attacking species. Often the most virulent pathogen strains are associated with diseased roots fed upon by insects (Caesar, 1996; Caesar et al., 1998). Strains of three Fusarium species, F. oxysporum Sclechtend.: Fr., F. solani (Mart) Sacc., and F. proliferatum (T. Matsushima) Nirenberg were highly virulent to leafy spurge in greenhouse tests (Caesar, 1996; Caesar et al., 1998). Field applications of a formulated strain of $F$. oxysporum have reduced stand density by as much as $30 \%$ over a single season (Caesar, unpublished). Thus, such strains would be good candidates for integrated control of leafy spurge when applied as a formulated product. To assess the potential of strains of Fusarium spp. as biological control agents, whether collected in North America or from the larger body of strains associated with insectdamaged leafy spurge in its native range overseas, information is needed on the effects of the strains on nontarget plants. Species with the greatest potential to be affected by their application are range grasses native to North America. Therefore, the objective of this study was to assess the impact of Fusarium spp. on mature grass plants and the stage of the plant most likely to experience any immediate impact. Furthermore, it is necessary to assess the effects of these pathogens on cultivated plant species to determine the level of risk associated with their potential release into agroecosystems. As an initial step to elucidate relationships among U.S. and European strains of Fusarium spp. from leafy spurge, a further objective was to assess the vegetative compatibility between strains from both areas. 


\section{Materials and methods}

\section{Storage of Fusarium spp.}

All strains were stored at $-80^{\circ} \mathrm{C}$ in a nutrient broth (Difco) amended with $15 \%$ glycerol and at $-20^{\circ} \mathrm{C}$ on sterile toothpicks or carnation leaves partially colonized by the strains.

\section{Effects of Fusarium spp. on biomass of native grasses}

The strains assessed in the present study have been described previously (Caesar, 1996; Caesar et al., 1998). The host ranges of the strains were assessed on 12 North American grass species listed in Table 1. European strains were tested in Rome, Italy and U.S. strains were tested in Bozeman, MT. The growth habits and seasonal characteristics of these grasses are also given in Table 1.

Table 1. North American native grasses used in this study.

\begin{tabular}{|c|c|c|c|c|}
\hline Species & Common name & Height $^{\mathrm{a}}$ & Season $^{b}$ & $\begin{array}{l}\text { Growth } \\
\text { habit }\end{array}$ \\
\hline $\begin{array}{l}\text { Agropyron dasystachyum } \\
\text { (Hook) Lams.-Scribn. }\end{array}$ & Thickspike wheatgrass & M & $\mathrm{C}$ & Sod \\
\hline $\begin{array}{l}\text { Agropyron riparium } \\
\quad \text { Lams.-Scribn. and J. G. Sm. }\end{array}$ & Streambank wheatgrass & S-M & $\mathrm{C}$ & Sod \\
\hline Andropogon gerardi Vitm. & Big Bluestem & $\mathrm{T}$ & $\mathrm{W}$ & Sod \\
\hline $\begin{array}{l}\text { Agropyron spicatum (Pursh.) } \\
\text { Lams.-Scribn. \& J. G. Sm. }\end{array}$ & Bluebunch wheatgrass & M & $\mathrm{C}$ & Bunch \\
\hline Andropogon hallii Hack. & Sand bluestem & $\mathrm{T}$ & $\mathrm{W}$ & Sod \\
\hline $\begin{array}{l}\text { Bouteloua gracilis (H. B. K.) } \\
\text { Lag. Ex Stend. }\end{array}$ & Blue grama & S-M & $\mathrm{W}$ & Bunch/Sod \\
\hline Elymus canadensis L. & Canada wildrye & $\mathrm{T}$ & $\mathrm{C}$ & Bunch \\
\hline Eragrostis tichodes (Nutt.) A. Wood & Sand lovegrass & $\mathrm{T}$ & $\mathrm{W}$ & Bunch \\
\hline Festuca idahoensis Elmer & Idaho fescue & $\mathrm{T}$ & $\mathrm{C}$ & Bunch \\
\hline Koeleria cristata Pers. & Prairie junegrass & M & $\mathrm{C}$ & Bunch \\
\hline Poa ampla Merr. & Big bluegrass & $\mathrm{T}$ & $\mathrm{C}$ & Bunch \\
\hline $\begin{array}{l}\text { Schizachyrium scoparium } \\
\text { (Michx.) Nash }\end{array}$ & Little bluestem & $\mathrm{M}$ & $\mathrm{W}$ & Bunch \\
\hline
\end{tabular}

Inocula for tests were prepared by culturing the strains in a $2 \%$ liquid medium in distilled water $(\mathrm{w} / \mathrm{v})$ consisting of Dietfiber (finely ground soybean hulls formerly manufactured by Lauhoff Grain Co., Danville, IL and containing ca $75 \%$ crude and soluble fiber, ca $10-12 \%$ protein, ca $1 \%$ fat, ca $5 \%$ ash, and ca $4 \%$ moisture, all w/w). The cultures were grown at $25^{\circ} \mathrm{C}$ for $2-3$ weeks with shaking and thoroughly mixed with a pasteurized greenhouse potting medium to achieve ca 150 colony-forming units (cfu) per g of air- 
dried soil mix. Populations of Fusarium were determined by plating four-fold dilutions of soil on Nash and Snyder medium (Nash and Snyder, 1962) and processing the data to obtain the most probable number of cfu (Clark and Owens, 1983).

In pathogenicity tests conducted with U.S. strains, the potting medium was a $1: 1: 1$ $\mathrm{v} / \mathrm{v} / \mathrm{v}$ Bozeman silt loam, peat, and sand, $\mathrm{pH} 6.6$, mixture. In tests conducted in Rome, the potting medium was a commercially sold mixture of $40 \%$ organic compost, $10 \%$ sand, $20 \%$ sphagnum peat moss and 30\% loam soil. The grass seeds were sown in $2.0-\mathrm{cm}-$ diameter Cone-tainers (Stuewe and Sons, Inc., Corvallis, OR), thinned to two seedlings per cell, and grown at $20-28^{\circ} \mathrm{C}$ in the greenhouse. Eight- to 10 -week-old plants were removed from 2-cm-diameter Cone-tainers and transplanted into 4-cm-diameter Conetainers of the infested soil. A treatment consisted of five Cone-tainers of soil mix infested with a strain of Fusarium and planted with a plug of a single grass species. Controls consisted of grass planted in 4-cm-diameter Cone-tainers containing uninfested soil. The grasses were grown at $20-28^{\circ} \mathrm{C}$ in the greenhouse, supplied with water every other day and Hoagland's solution weekly, and harvested 24 weeks after transplanting into infested soil. At harvest, grass plants were removed from Cone-tainers, washed free of the soil mix, dried at $28^{\circ} \mathrm{C}$, and weighed. After weighing, samples of root and crown tissues were plated on water agar. The tests were repeated twice. Data were tested to confirm homogeneity of variances by the method of Bartlett and Kendall (1946) prior to pooling data from all trials for analysis using Waller and Duncan's exact Bayesian k-ratio LSD rule $(P$ $=0.05$ ) (Waller and Duncan, 1969).

\section{Tests of pathogenicity on cultivated species}

Three-week-old seedlings of 27 cultivated species were subjected to pathogenicity tests of each of the U.S. strains of Fusarium spp. using root-dip assays (Elmer, 1991; Katan et al., 1994; MacDonald and Leach, 1976; Rowe, 1980; Salgado and Schwartz, 1995; Swanson and Van Gundy, 1985). Testing of U.S. strains was conducted in Bozeman, MT. Testing of European strains on 12 cultivated species was conducted in Rome, Italy. Seed of various species were planted in the appropriate artificial potting mix described in the previous section in 24 to 48 -cell plastic planting trays consisting of 5-to 6-cm-square cells or sections (liners). Thinning 10 days after emergence resulted in 2 seedlings per cell. Inocula for root-dip assays were prepared as liquid cultures of $2 \%(\mathrm{w} / \mathrm{v})$ Dietfiber at $20-28^{\circ} \mathrm{C}$ with shaking and filtered through two layers of cheesecloth. Suspensions consisting of microconidia, macroconidia, and chlamydospores ( $F$. oxysporum and $F$. solani) or macroconidia and microconidia $\left(F\right.$. proliferatum) were prepared at $10^{6} \mathrm{cfu} / \mathrm{ml}$ using a hemacytometer to estimate spore concentrations. Roots of 3-week-old seedlings of various species were removed from trays, carefully washed free of soil, and dipped for 3-5 min in spore suspensions prior to planting. Five seedlings per strain were dipped and planted in 7.5-cm-diameter pots completely randomized by treatment. Species inoculated were alfalfa (Medicago sativa L.) cv Washoe, artichoke (Cynara cardunculus L.) cv Green Globe, asparagus (Asparagus officianalis L.) cv Mary Washington, bachelors button (Centaurea cyanus L.) cv Finest Mixed, barley (Hordeum vulgare L.), field corn (Zea mays L.), carnation (Dianthus caryophyllus L.) cv Chabaud, sweet corn (Zea mays L.) cv Golden Bantam, cotton (Gossypium hirsutum L.) cv Stoneville 7A, cowpea (Vigna unguiculata ((L.) Walp.) cv California Blackeye, flax (Linum ussitatissimum L.) cultivar 
Punjab, mung bean (Phaseolus aureus L.-Vigna radiata (L.) R. Wilcz.) cv Berken, muskmelon (Cucumis melo L. var. reticulatus) cv Earliqueen, oats (Avena sativa L.), okra (Hibiscus esculentus L.) cv Clemson Spineless, peanut (Arachis hypogea L.) cv Virginia Jumbo, rice (Oryza sativa L.), rye (Secale cereale L.), safflower (Carthamus tinctorus L.), snapbean (Phaseolus vulgaris L.) cv Blue Lake 274, sorghum (Sorghum bicolor (L.) Moench), soybean (Glycine max (L.) Merr.) cultivar Essex, sugarbeet (Beta vulgaris L.), garden beet (Beta vulgaris L.) cv Detroit Red, sunflower (Helianthus anuus L.) cv D131, (Lycopersicon esculentum Miller) cv Bonny Best, wheat (Triticum aestivum L.), and zinnia (Zinnia violacea Cav.) cv State Fair Mixed. In tests conducted in Rome, 3-week-old seedlings of asparagus, bachelors button, carnation, corn, flax, muskmelon, okra, snapbean, tomato, and zinnia, each of the same cultivar as above, were used. Inoculated seedlings were planted into soil mix in liners or 4-cm-diameter Cone-tainers, grown at $20-25^{\circ} \mathrm{C}$, and observed for the symptoms described in previous studies using the root-dip assay to test pathogenicity on various species. Respective controls for all tests consisted of seedlings dipped in water prior to replanting in pasteurized soil mix. If seedling mortality or chlorosis was observed within 3 weeks after tests began, the test was scored as positive. The test plants were then left to grow for another 6 weeks in the greenhouse for further observation. If chlorosis or apparent stunting of any replicate was observed relative to the control for any plant species, all plants of the species were harvested, dried at $28^{\circ} \mathrm{C}$, and weighed. Samples of root and crown tissue of weighed plants were plated onto water agar to detect the presence of the respective inoculated strain. These series of tests were repeated twice. Data were tested to confirm homogeneity of variances by the method of Bartlett and Kendall (1946) prior to pooling data from all trials for analysis using Waller and Duncan's exact Bayesian k-ratio LSD rule $(P=0.05)$ (Waller and Duncan, 1969).

\section{Vegetative compatibility group testing of Fusarium oxysporum strains}

Several defined nitrogen source media (FDNS) were prepared by amending a minimal medium (MM) containing 3\% sucrose and $0.17 \%$ yeast nitrogen base without amino acids or ammonium sulfate (Difco) (Pulhalla, 1985; V. Miller, personal communication) with one of several different nitrogen sources (Correll et al., 1987). The MM amended with 5\% sodium chlorate (YC) was used to generate nitrate nonutilizing mutants (nit) (Pulhalla, 1985). FDNS were used to characterize phenotypically nit mutants and the nitrate FDNS was used to recognize nit mutants and for complementation (heterokaryon) tests. Nit mutants were generated by placing small mycelial plugs of Fusarium strains on YC medium and observing for fast growing sectors over 4-10 days. The nit mutants were then grown on FDNS to phenotypically characterize the mutants. Three different nit mutants, nit 1 , nit 3 , and nit $\mathrm{M}$ were obtained from all four $F$. oxysporum strains and the single strain of $F$. proliferatum. Some nit mutants were obtained from two of the four strains of F. solani: two nit mutants, nit 1 and $n i t \mathrm{M}$, were generated from $94 \mathrm{f}-15$ and a single $n i t \mathrm{M}$ mutant was generated for 94f-24. U.S. nit mutants were paired in all possible combinations with European nit mutants on nitrate FDNS, and pairings were scored as vegetatively compatible when wild-type mycelial growth occurred within 2 weeks at colony interfaces between mutant strains. All complementation tests were made at least twice. 


\section{Results}

\section{Effects of European and U.S. strains on native grasses}

One or more U.S. strains of Fusarium spp. pathogenic to leafy spurge caused significant reductions in dry weight of 3 of 12 species of North American grasses: Idaho fescue, big bluestem, and big bluegrass, 24 weeks after the grasses were planted in soil infested with the various strains. In no instance was seed-head production affected. Seed was produced by all grasses, although total seed production was not measured. Reductions in dry weight of Idaho fescue were caused by strains Lyman Creek 4A, Sidney 3Y, MT94-20,

Table 2. Results of host-range tests of Fusarium spp. from the U.S. northern plains on 27 cultivated species and 12 native grasses.

\begin{tabular}{|c|c|c|c|c|c|}
\hline $\begin{array}{l}\text { Strain and U.S. } \\
\text { state of origin }{ }^{a}\end{array}$ & Species & $\begin{array}{l}\text { Virulence } \\
\text { Ranking }\end{array}$ & $\begin{array}{l}\text { Cultivated species } \\
\text { with significant } \\
\text { reductions in dry } \\
\text { weight and per- } \\
\text { centage of reduc- } \\
\text { tion in brackets }{ }^{c, f}\end{array}$ & $\begin{array}{l}\text { Cultivated species with } \\
\text { reaction to root-dip as- } \\
\text { say and symptoms }{ }^{d}\end{array}$ & $\begin{array}{l}\text { North American native } \\
\text { grasses with significant } \\
\text { reductions in dry weight } \\
\text { and percentage of reduction } \\
\text { in brackets }{ }^{e, f}\end{array}$ \\
\hline $\begin{array}{l}\text { ND94-8 } \\
\text { North Dakota }\end{array}$ & $\begin{array}{l}\text { Fusarium } \\
\text { oxysporum }\end{array}$ & 1 & None & $\begin{array}{l}\text { Flax } \\
\quad \text { (chlorosis and wilt) }\end{array}$ & None \\
\hline $\begin{array}{l}\text { Lyman Creek 4A } \\
\text { Montana }\end{array}$ & F. oxysporum & 2 & None & None & $\begin{array}{l}\text { Idaho fescue }(58 \%) \\
\text { Big bluestem }(87 \%) \\
\text { Big bluegrass }(71 \%)\end{array}$ \\
\hline $\begin{array}{l}\text { Fairy Soil 3B } \\
\text { Montana }\end{array}$ & F. oxysporum & 3 & None & None & Big bluestem (83\%) \\
\hline $\begin{array}{l}\text { McLain } 2 \\
\quad \text { Montana }\end{array}$ & F. oxysporum & 4 & $\begin{array}{l}\text { Sorghum }(65 \%) \\
\text { Sugarbeet }(71 \%) \\
\text { Cantaloupe }(80 \%)\end{array}$ & $\begin{array}{l}\text { Okra } \\
\text { (seedling mortality) }\end{array}$ & None \\
\hline $\begin{array}{l}\text { Sidney 3Y } \\
\text { Montana }\end{array}$ & F. proliferatum & 5 & None & $\begin{array}{l}\text { Cotton } \\
\text { (seedling mortality) }\end{array}$ & $\begin{array}{l}\text { Idaho fescue }(57 \%) \\
\text { Big bluestem }(92 \%) \\
\text { Big bluegrass }(56 \%)\end{array}$ \\
\hline $\begin{array}{l}\text { Fairy Soil 3V } \\
\text { Montana }\end{array}$ & F. solani & 6 & None & None & None \\
\hline $\begin{array}{l}\text { ND94-10 } \\
\text { North Dakota }\end{array}$ & F. oxysporum & 7 & None & None & Big bluestem (64\%) \\
\hline $\begin{array}{l}\text { MT94-20 } \\
\text { Montana }\end{array}$ & F. oxysporum & 8 & None & None & Idaho fescue $(60 \%)$ \\
\hline $\begin{array}{l}\text { ND94-5 } \\
\text { North Dakota }\end{array}$ & F. oxysporum & 9 & None & None & None \\
\hline $\begin{array}{l}\text { ND94-6a } \\
\text { North Dakota }\end{array}$ & F. solani & 10 & Safflower (72\%) & None & None \\
\hline $\begin{array}{l}\text { WY94-11-4 } \\
\text { Wyoming }\end{array}$ & F. oxysporum & 11 & None & None & $\begin{array}{l}\text { Idaho fescue }(62 \%) \\
\text { Big bluestem }(77 \%)\end{array}$ \\
\hline \multicolumn{6}{|c|}{$\begin{array}{l}{ }^{a} \text { Detailed collection locations, collection dates, symptomatology on original host, and association with insect damage } \\
\text { have been previously described (Caesar, 1996). } \\
{ }^{b} \text { Based on 0-6 rating scale of disease of leafy spurge planted in soil infested with equal populations of Fusarium spp. } \\
\text { (Caesar, 1996). } \\
{ }^{c} \text { Cultivated species (of } 27 \text { tested) which exhibited reduced dry weight within } 9 \text { weeks after transplanting into green- } \\
\text { house soil mix following root-dip assays using spore concentrations of } 10^{6} \text { spores } / \mathrm{ml} \text {. Expressed as a percentage com- } \\
\text { pared to the untreated control. See Materials and Methods for a list of cultivated species screened in host range tests. } \\
{ }^{d} \text { Cultivated species (of } 27 \text { tested) which exhibited mortality or symptoms of vascular wilt, compared to the untreated } \\
\text { control (water dip) in greenhouse tests within } 3 \text { weeks following root-dip assays using a spore concentration of } 10^{6} \\
\text { spores/ml. } \\
\left.{ }^{e} \text { Significant reductions in dry weight ( } P=0.05\right) 9 \text { weeks after planting into greenhouse soil mix infested with Fusa- } \\
\text { rium spp. At } 150 \text { cfu/g of air-dried soil mix. See Table } 1 \text { for a list of North American native grass species tested. } \\
f^{f} \text { Significant differences were determined using ANOVA followed by Waller and Duncan's exact Bayesian k-ratio } \\
\text { LSD rule. }\end{array}$} \\
\hline
\end{tabular}

Page 6 of 11 
and WY94-11-4 and ranged from 57 to $62 \%$ (Table 2). Dry weights of big bluestem were significantly reduced by five strains, Lyman Creek 4A, Fairy Soil 3B, Sidney 3Y, ND94-10, and WY94-11-4, and ranged from 64 to 92\%. Two strains, Lyman Creek 4A and Sidney 3 Y, significantly reduced dry weight of big bluegrass by 71 and $56 \%$, respectively. A strain, ND94-8, highly virulent in a previous study, failed to affect any grass negatively. Similarly, strains McLain 2, Fairy Soil 3V, ND94-5, and ND94-6a failed to have any effect on native grasses. Only a single European strain of $F$. solani tested, 94f-24, significantly reduced the biomas of any of the 12 North American grasses in tests overseas over 24 weeks (Table 3).

Table 3. Results of host-range tests of Fusarium spp. from Europe on 12 cultivated species and 12 native grasses.

\begin{tabular}{|c|c|c|c|c|c|}
\hline $\begin{array}{l}\text { Strain and } \\
\text { country } \\
\text { of origin }\end{array}$ & Species & $\begin{array}{l}\text { Virulence } \\
\text { ranking } \\
\text { vs spurge }^{b}\end{array}$ & $\begin{array}{l}\text { Cultivated species } \\
\text { with significant } \\
\text { reductions in dry } \\
\text { weight and percent- } \\
\text { age of reduction in } \\
\text { brackets }\end{array}$ & $\begin{array}{l}\text { Cultivated } \\
\text { species } \\
\text { with } \\
\text { reaction to } \\
\text { root-dip } \\
\text { assay and } \\
\text { symptoms }\end{array}$ & $\begin{array}{l}\text { North American native } \\
\text { grasses with significant } \\
\text { reductions in dry weight } \\
\text { and percentage of } \\
\text { reduction in brackets }\end{array}$ \\
\hline 94f-5 Russia & $\begin{array}{l}\text { Fusarium } \\
\text { oxysporum }\end{array}$ & 1 & None & None & None \\
\hline 94f-37 France & F. oxysporum & 2 & None & None & None \\
\hline 94f-25 Russia & F. solani & 3 & $\begin{array}{l}\text { Muskmelon (100\%) } \\
\text { Zinnia }(100 \%) \\
\text { Snapbean }(100 \%)\end{array}$ & $\begin{array}{l}\text { None } \\
\text { None } \\
\text { None }\end{array}$ & $\begin{array}{l}\text { None } \\
\text { None } \\
\text { None }\end{array}$ \\
\hline 94f-24 Russia & F. solani & 4 & None & None & Sand lovegrass (53\%) \\
\hline 94f-11 Russia & F. oxysporum & 5 & $\begin{array}{l}\text { Okra }(100 \%) \\
\text { Muskmelon }(88 \%) \\
\text { Zinnia }(100 \%) \\
\text { Snapbean }(73 \%)\end{array}$ & $\begin{array}{l}\text { None } \\
\text { None } \\
\text { None } \\
\text { None }\end{array}$ & $\begin{array}{l}\text { None } \\
\text { None } \\
\text { None } \\
\text { None }\end{array}$ \\
\hline 94f-15 Russia & F. solani & 6 & $\begin{array}{l}\text { Snapbean }(100 \%) \\
\text { Zinnia }(98 \%)\end{array}$ & $\begin{array}{l}\text { None } \\
\text { None }\end{array}$ & $\begin{array}{l}\text { None } \\
\text { None }\end{array}$ \\
\hline 93f-17D Russia & F. oxysporum & 7 & Snapbean $(100 \%)$ & None & None \\
\hline 94f-29 Russia & F. solani & 8 & None & None & None \\
\hline 94-30 Russia & $F$. proliferatum & 9 & None & None & None \\
\hline Control & & - & - & - & - \\
\hline \multicolumn{6}{|c|}{$\begin{array}{l}{ }^{a} \text { Detailed collection locations, collection dates, symptomatology on original host and association with insect damage } \\
\text { have been previously described (Caesar et al., 1998). } \\
{ }^{b} \text { Based on 0-6 rating scale of disease of leafy spurge planted in soil infested with equal populations of Fusarium spp. } \\
\text { (Caesar } \text { et al., 1998). } \\
{ }^{c} \text { Cultivated species (of } 12 \text { tested) which exhibited reduced dry weight within } 9 \text { weeks after transplanting into green- } \\
\text { house soil mix following root-dip assays using spore concentrations of } 10^{6} \text { spores } / \mathrm{ml} \text {. Expressed as a percentage } \\
\text { compared to untreated control. Cultivated species included in this host range are listed under Materials and Methods. } \\
{ }^{d} \text { Cultivated species (of } 12 \text { tested) which exhibited mortality or symptoms of vascular wilt, compared to the untreated } \\
\text { control (water dip), in greenhouse tests within } 3 \text { weeks following root-dip assays using a spore concentration of } 10^{6} \\
\text { spores/ml. } \\
{ }^{e} \text { Significant reductions in dry weight (P=0.05) } 9 \text { weeks after planting into greenhouse soil mix infested with } 150 \mathrm{cfu} / \mathrm{g} \\
\text { of air-dried soil mix of Fusarium spp. See Table } 1 \text { for a list of North American native grass species tested. } \\
{ }^{f} \text { Significant differences were determined using ANOVA followed by Waller and Duncan's exact Bayesian k-ratio LSD } \\
\text { rule. }\end{array}$} \\
\hline
\end{tabular}




\section{Effects of U.S. strains on 27 cultivated species}

Using root-dip assays, cotton and okra were found to exhibit seedling mortality due to McLain 2 and Sidney 3 Y, respectively (Table 2). Flax exhibited chlorosis and wilt within 3 weeks after the assay, caused by ND94-8, although this was not reflected in a reduction in dry weight over a total of 9 weeks of growth. McLain 2 caused significant reductions $(P=0.05)$ in dry weight of sorghum, sugarbeet, and cantaloupe, of 65,71 , and $80 \%$, respectively. Strains of Fusarium spp. reduced dry weights of only 4 (cantaloupe, sorghum, sugarbeet, and safflower) of 27 cultivated species when plants from root-dip assays were allowed to grow for 9 weeks after planting. However, a single strain of $F$. oxysporum, McLain 2, caused three instances of such dryweight reductions.

\section{Effects of European strains on 12 cultivated species}

Neither of the two most virulent European strains, 94f-5 and 94f-37, both previously identified as F. oxysporum (Caesar et al., 1998), caused apparent disease or reduced dry weight of any of 12 cultivated species on which they were tested (Table 3). No European strain caused disease within 3 weeks after inoculation by root-dip. Four European strains, two identified as $F$. solani, $94 \mathrm{f}-25$ and $94 \mathrm{f}-15$, and two as $F$. oxysporum, $94 \mathrm{f}-11$ and 93f-17D, caused mortality to 1 or more cultivated species within 9 weeks but after 3 weeks following root-dip assays. Cultivated species which exhibited complete mortality in all replications between 3 and 9 weeks after root-dips were muskmelon, zinnia, snapbean, and okra. The widest range of hosts attacked by the four strains was 4 species, exhibited by $94 \mathrm{f}-11$, with the three other strains, $94 \mathrm{f}-25,94 \mathrm{f}-15$, and $93 \mathrm{f}-17 \mathrm{D}$, exhibiting host ranges of 3,2 , and 1 species, respectively.

\section{Vegetative compatibility tests}

Two strains of $F$. proliferatum, one from Sidney, MT (Sidney 3Y), the other from Tatarka, Russia (94f-30) were vegetatively compatible. The Russian strain was isolated from dead root adventitious buds of Euphorbia virgata and was ranked lowest in virulence among nine strains from Europe described in a previous study (Caesar et al., 1998). No other pairing of a European and a U.S. strain resulted in vegetative compatibility.

\section{Discussion}

The widest range of hosts attacked by any U.S. strain of Fusarium spp. on 12 North American grasses was three, exhibited by two strains, Sidney $3 \mathrm{Y}$ and Lyman Creek 4A. Only one European strain, 94f-24, significantly reduced the dry weight of any of the 12 North American grasses. The widest range of hosts attacked by any U.S. strain when tested on 27 cultivated species was three. The widest range of hosts of any European strain on 12 cultivated species was four, exhibited by one strain, 94f-11. Three of the five most virulent U.S. strains of Fusarium spp., based on a previous study (Caesar, 1996), exhibited the widest host ranges against either North American grasses or cultivated species. However, of the four most virulent European strains, only one, 94f-25, was patho- 
genic to more than 1 cultivated species or North American grass. Additionally, neither of the two European strains most virulent to leafy spurge, among nine assessed, caused disease or reduced the biomass of any of 12 cultivated crop and 12 North American grass species tested. A critical criterion for the potential utility of Fusarium spp. as a biological control agent of a target weed is the host range, particularly among North American grasses. Such grasses are the nontarget plants with the greatest and most immediate chance of being impacted should any of the Fusarium spp. be applied to stands of leafy spurge for biological control. These collective results are promising and justify wider search and screening of strains with high virulence and narrow host ranges. These results also provide preliminary indication that searches beyond North America could potentially lead to safer strains for use as biocontrol agents of weeds.

The need for more extensive search and screening is further supported by existing knowledge of host specificity among Fusarium spp. in general. Formae speciales of $F$. oxysporum and $F$. solani, especially wilt-causing $F$. oxysporum, often exhibit pronounced host specificity (Booth, 1971). For example, formae speciales that are restricted in host range to a single species (Snyder, 1941) or to subspecific groups within a single species (Armstrong and Armstrong, 1976) have been identified. An alternative model of pathogenicity and host range would be that of F. oxysporum f. sp. Radicislycopersici (Rowe, 1980), a forma specialis consisting of root- and crown-rot pathogens that are highly host specific (Jarvis et al., 1975) or typically have a wider host range while exhibiting greater virulence to the host of origin (Rowe, 1980). Based on the symptomatology for these European strains, as mostly root- and crown-rot pathogens (Caesar et al., 1998), and the host ranges described herein, they may more closely resemble the former pattern for strains of $F$. oxysporum f. sp. radicis-lycopersici. The U.S. strains seem to be more similar to wilt Fusaria, based on a previous study (Caesar, 1996). Testing of U.S. strains isolated since an earlier study has supported this hypothesis (Caesar, unpublished). Studies of the host range of Fusarium spp. within the two subgeneric taxa that define the closest wild and endangered relatives of Euphorbia esula (Pemberton, 1985) are needed.

One U.S. and 1 European strain of $F$. proliferatum were vegetatively compatible. Of the 11 strains compared in a previous study (Caesar, 1996), the U.S. strain was moderately ranked in virulence, whereas the European strain was of comparatively low virulence among the 9 strains compared in another study (Caesar et al., 1998). This finding confirms earlier research (Jacobson and Gordon, 1990; Elmer, 1991) showing that virulence may vary within a single vegetative compatibility group (VCG). Apparently there is also variation in host range within a single VCG, based on the present findings that the U.S. strain of $F$. proliferatum severely affected three grass species native to North America and one cultivated species, whereas the European strain failed to affect any species.

Diseased leafy spurge plants are more widespread and ubiquitous in Eurasia than in North America and occur within small, nondescript stands along roadsides and in natural areas. Thus, there is a greater pool of diseased spurge from which desirable strains may be isolated, tested, and selected. The frequency with which highly virulent, narrow host-range strains of Fusarium were found, as indicated by the present data and a previous study on European Fusarium spp. (Caesar et al., 1998), additionally shows that surveys beyond North America are promising. Evidence for these Fusarium strains and for other formae speciales indicates that searches for narrow host-range/high-virulence 
strains in Eurasia may not necessarily result in strains highly exotic to North America since Fusarium spp. are cosmopolitan and ubiquitous. The evidence includes the similarity in the range of pathogen species associated with diseased or insect-damaged roots of leafy spurge in the U.S. and Europe, respectively, and the vegetative compatibility of U.S. and European strains of at least one species, $F$. proliferatum. In addition, no wide divergence in the host ranges was observed between foreign and domestic strains of any of three Fusarium spp. pathogenic to leafy spurge. Finally, the finding that the two most virulent European strains were the two strains with the narrowest host ranges among all U.S. and European strains assessed strengthens this view.

\section{References}

Armstrong, G. M. and Armstrong, J. K. 1976. Common hosts for Fusarium oxysporum formae speciales spinaciae and betae. Phytopathology 66, 542-545.

Bangsund, D. A. and Leistritz, F. L. 1991. Economic Impacts of Leafy Spurge on Grazing Lands in the Northern Great Plains. NDSU Agricultural Economics Report No. 275-S.

Bartlett, M. S. and Kendall, D. G. 1946. The statistical analysis of variances - heterogeneity and the logarithmic transformation. J. R. Stat. Soc. 8 (Suppl.), 128-138.

Booth, C. 1971. The Genus Fusarium. Eastern Press, London.

Caesar, A. J. 1996. Identity, pathogenicity, and comparative virulence of Fusarium spp. related to stand declines of leafy spurge in the Northern Plains. Plant Dis. 80, 1395-1398.

Caesar, A. J., Campobasso, G., and Terragitti, G. 1998. Identification, pathogenicity and comparative virulence of Fusarium spp. associated with diseased Euphorbia spp. in Europe. Biocontrol Sci. Technol. 8, 313-319.

Clark, K. R., and Owens, N. J. P. 1983. A simple and versatile microcomputer program for the determination of most probable number.J. Microbiol. Methods 1, 133-137.

Correll, J. C., Klittich, C. J. R., and Leslie, J. F. 1987. Nitrate nonutilizing mutants of Fusarium oxysporum and their use in vegetative compatibility tests. Phytopathology 77, 1640-1646.

Elmer, W. H. 1991. Vegetative compatibility groups of Fusarium proliferatum from asparagus and comparisons of virulence, growth rates, and colonization of Asparagus residues among groups. Phytopathology 81, 852-857.

Jacobson, D. J. and Gordon, T. R. 1990. Vegetative compatibility and self-incompatibility within Fusarium oxysporum f. sp. melonis. Phytopathology 78, 668-672.

Jarvis, W. R., Thorpe, H. J., and MacNeill, B. H. 1975. Afoot and root rot disease of tomato caused by Fusarium oxysporum. Can. Plant Dis. Surv. 55, 25-26.

Katan, T., Katan, J., Gordon, T. R., and Pozniak, D. 1994. Physiologic races and vegetative compatibility groups of Fusarium oxysporum f. sp. melonis in Israel. Phytopathology 84, 153-157.

MacDonald, J. D., and Leach, J. D. 1976. The association of Fusarium oxysporum f. sp. betae with nonprocessed and processed sugarbeet seed. Phytopathology 66, 868-872.

Nash, S. M. and Snyder, W. C. 1962. Quantitative estimations by plate counts of propagules of bean root rot Fusarium in field soils. Phytopathology 52, 567-572.

Pemberton, R. W. 1985. Native plant considerations in the biological control of leafy spurge. In Proceedings of the VI International Symposium on the Biological Control of Weeds (E. S. Delfosse, Ed.), pp. 365-390. Agriculture Canada, Ottawa, Ontario. 
Pulhalla, J. E. 1985. Classification of strains of Fusarium oxysporum on the basis of vegetative compatibility. Can. J. Bot. 63, 179-183.

Rowe, R. C. 1980. Comparative pathogenicity and host ranges of Fusarium oxysporum isolates causing crown and root rot of greenhouse and field-grown tomatoes in North America and Japan. Phytopathology 70, 1143-1148.

Salgado, M. O. and Schwartz, H. F. 1995. Inheritance of resistance to a Colorado race of Fusarium oxysporum f. sp. phaseoli in common bean. Plant Dis. 79, 279-281.

Snyder, W. C. 1941. A Fusarium wilt of sweet william (Dianthus barbatus). Phytopathology 31, 1054-1056.

Swanson, T. A., and Van Gundy, S. D. 1985. Influences of temperature and plant age on differentiation of races of Fusarium oxysporum f. sp. tracheiphilum on cowpea. Plant Dis. 69, 779-781.

Waller, R. A., and Duncan, D. B. 1969. A Bayes rule for the symmetric multiple comparison problem. J. Am. Stat. Assoc. 64, 1484-1499. 